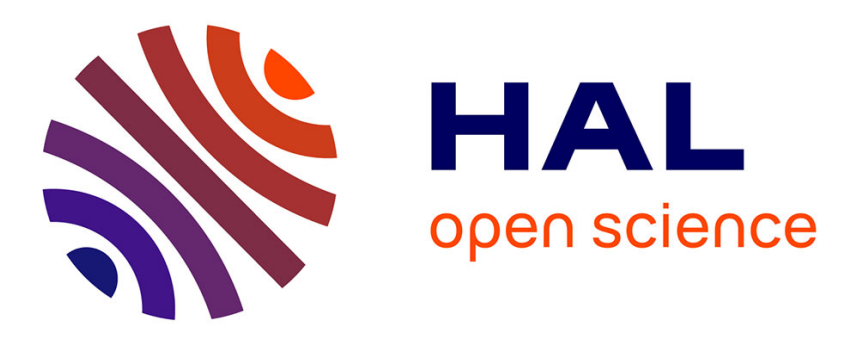

\title{
Insertion of Methylthiirane into the P-I Bonds of $\alpha$-P4S3I2
}

Bruce William Tattershall, Nicholas Geneux, Kathryn Holmes, Michael Hargreaves, Glenn Mcmorrow

\section{- To cite this version:}

Bruce William Tattershall, Nicholas Geneux, Kathryn Holmes, Michael Hargreaves, Glenn Mcmorrow. Insertion of Methylthiirane into the P-I Bonds of $\alpha$-P4S3I2. Journal of Inorganic and General Chemistry / Zeitschrift für anorganische und allgemeine Chemie, 2009, 635 (13-14), pp.2222. 10.1002/zaac.200900235 . hal-00518303

\section{HAL Id: hal-00518303 https://hal.science/hal-00518303}

Submitted on 17 Sep 2010

HAL is a multi-disciplinary open access archive for the deposit and dissemination of scientific research documents, whether they are published or not. The documents may come from teaching and research institutions in France or abroad, or from public or private research centers.
L'archive ouverte pluridisciplinaire HAL, est destinée au dépôt et à la diffusion de documents scientifiques de niveau recherche, publiés ou non, émanant des établissements d'enseignement et de recherche français ou étrangers, des laboratoires publics ou privés. 


\section{Zeitschrift für Anorganische und}

Allgemeine Chemie

\section{Insertion of Methylthiirane into the P-I Bonds of $a-P_{4} S_{3} I_{2}$}

\begin{tabular}{|c|c|}
\hline Journal: & Zeitschrift für Anorganische und Allgemeine Chemie \\
\hline Manuscript ID: & zaac.200900235.R1 \\
\hline Wiley - Manuscript type: & Article \\
\hline $\begin{array}{r}\text { Date Submitted by the } \\
\text { Author: }\end{array}$ & 29-Jul-2009 \\
\hline Complete List of Authors: & $\begin{array}{l}\text { Tattershall, Bruce; Newcastle University, School of Chemistry } \\
\text { Geneux, Nicholas; Newcastle University, School of Chemistry } \\
\text { Holmes, Kathryn; Newcastle University, School of Chemistry } \\
\text { Hargreaves, Michael; Newcastle University, School of Chemistry } \\
\text { McMorrow, Glenn; Newcastle University, School of Chemistry }\end{array}$ \\
\hline Keywords: & $\begin{array}{l}\text { Phosphorus, Sulfur heterocycles, Insertions, Chiral Cage, NMR (31P, } \\
13 C)\end{array}$ \\
\hline \multicolumn{2}{|c|}{$\begin{array}{l}\text { Note: The following files were submitted by the author for peer review, but cannot be converted } \\
\text { to PDF. You must view these files (e.g. movies) online. }\end{array}$} \\
\hline $\begin{array}{l}\text { Scheme 1.cdx } \\
\text { Scheme 2.cdx }\end{array}$ & \\
\hline
\end{tabular}

\section{S) ScholaroNE \\ Manuscript Central}




\title{
ARTICLE
}

DOI: 10.1002/zaac.200((will be filled in by the editorial staff))

\section{Insertion of Methylthiirane into the P-I Bonds of $\alpha-\mathrm{P}_{4} \mathrm{~S}_{3} \mathrm{I}_{2}$}

\author{
Bruce W. Tattershall ${ }^{*}$, Nicholas S. Geneux, Kathryn E. Holmes, Michael D. Hargreaves and Glenn \\ McMorrow
}

Keywords: Phosphorus; Sulfur heterocycles; Insertions; Chiral Cage; NMR $\left({ }^{31} \mathrm{P},{ }^{13} \mathrm{C}\right)$

\begin{abstract}
Rac-methylthiirane inserted into the P-I bonds of $\begin{array}{lll}\alpha-\mathrm{P}_{4} \mathrm{~S}_{3} \mathrm{I}_{2}, \quad \text { giving two diastereomers } & \text { of } \\ \text { exo,exo- } \alpha-\mathrm{P}_{4} \mathrm{~S}_{3}\left(\mathrm{SCHMeCH}_{2} \mathrm{I}\right) \mathrm{I} & \text { and three diastereomers of }\end{array}$ exo,exo- $\alpha-\mathrm{P}_{4} \mathrm{~S}_{3}\left(\mathrm{SCHMeCH}_{2} \mathrm{I}\right)_{2}$, as kinetic products, identified by ${ }^{31} \mathrm{P}$ and ${ }^{13} \mathrm{C}$ NMR in the reaction solutions. Ab initio modelling, using the DF MPW1PW91 method, showed that corresponding products containing the $\mathrm{SCH}_{2} \mathrm{CHIMe}$ substituent should be more stable, but only $\alpha-\mathrm{P}_{4} \mathrm{~S}_{3}\left(\mathrm{SCHMeCH}_{2} \mathrm{I}\right)\left(\mathrm{SCH}_{2} \mathrm{CHIMe}\right)$ was suggested by the NMR evidence as a lower yield product. The initially

heating or in the presence of the sulfur transfer catalyst $\operatorname{Re}(\mathrm{O}) \mathrm{Cl}_{3}\left(\mathrm{PPh}_{3}\right)_{2}$, to give low concentrations of $\alpha-\mathrm{P}_{4} \mathrm{~S}_{3}(\mathrm{~S})\left(\mathrm{SCHMeCH}_{2} \mathrm{I}\right) \mathrm{I}$ and $\alpha-\mathrm{P}_{4} \mathrm{~S}_{3}(\mathrm{~S})\left(\mathrm{SCHMeCH}_{2} \mathrm{I}\right)_{2}$, in which a 1-coordinate sulfur atom was attached to a phosphorus atom carrying the thiolate group. The number of diastereomers appropriate for only one orientation of the terminal sulfur relative to the cage skeleton was found in significant concentration in each case, in contrast to previous work on sulfurisation of $\alpha-\mathrm{P}_{4} \mathrm{~S}_{3}$ diamides.
\end{abstract} formed thiolates were sulfurised by further methylthiirane on with $\alpha-\mathrm{P}_{4} \mathrm{~S}_{3}\left(\mathrm{NPr}_{2}^{\mathrm{i}}\right)_{2}$ to give good ${ }^{31} \mathrm{P}$ NMR spectra of some of the isomers of $\alpha-\mathrm{P}_{4} \mathrm{~S}_{3}(\mathrm{~S})\left(\mathrm{NPr}_{2}^{\mathrm{i}}\right)_{2}$ reported previously, along with related ${ }^{31} \mathrm{P}$ NMR spectra of new phosphorus sulfide amide cage compounds, which have not been identified [5]. In the present work we have investigated whether the methylthiirane method could be used also to sulfurise $\alpha-\mathrm{P}_{4} \mathrm{~S}_{3} \mathrm{I}_{2}$.

\section{((Insert Scheme 1 here, single column width))}

Instead of sulfurisation, with elimination of propene, methylthiirane inserted into one or both $\mathrm{P}-\mathrm{I}$ bonds of $\alpha-\mathrm{P}_{4} \mathrm{~S}_{3} \mathrm{I}_{2}$, to give the new thiolato derivatives $\alpha-\mathrm{P}_{4} \mathrm{~S}_{3}\left(\mathrm{SCHMeCH}_{2} \mathrm{I}\right) \mathrm{I}$ and $\alpha-\mathrm{P}_{4} \mathrm{~S}_{3}\left(\mathrm{SCHMeCH}_{2} \mathrm{I}\right)_{2}$, identified in the reaction mixture by ${ }^{31} \mathrm{P}$ and ${ }^{13} \mathrm{C}$ NMR. Starting from racemic methylthiirane, the expected two diastereomers of the thiolate iodide, and three diastereomers of the dithiolate, were observed. In the presence of the rhenium catalyst, or on heating the mixture to $60{ }^{\circ} \mathrm{C}$ without the catalyst, these reacted further to give low concentrations of $\alpha-\mathrm{P}_{4} \mathrm{~S}_{3}(\mathrm{~S})\left(\mathrm{SCHMeCH}_{2} \mathrm{I}\right) \mathrm{I}$ (two diastereomers) or $\alpha-\mathrm{P}_{4} \mathrm{~S}_{3}(\mathrm{~S})\left(\mathrm{SCHMeCH}_{2} \mathrm{I}\right)_{2} \quad$ (four diastereomers). Methylthiirane is known to insert into a $\mathrm{P}-\mathrm{Cl}$ bond of $\mathrm{MePCl}_{2}$ at $60{ }^{\circ} \mathrm{C}[6]$. Simple $\alpha-\mathrm{P}_{4} \mathrm{~S}_{3}$ dithiolates $1(\mathrm{X}=\mathrm{Y}=$ $\mathrm{SMe}, \mathrm{SEt}$ or $\mathrm{SPh}$ ) are known [7], but in the $\alpha-\mathrm{P}_{4} \mathrm{~S}_{3}$ thiolate iodide series, only $\alpha-\mathrm{P}_{4} \mathrm{~S}_{3}(\mathrm{SPh}) \mathrm{I}$ has been reported, as being formed in less than the expected relative quantities in the reaction of $\alpha-\mathrm{P}_{4} \mathrm{~S}_{3} \mathrm{I}_{2}$ with $\mathrm{PhSH}$ and $\mathrm{Et}_{3} \mathrm{~N}$ [8]. Its ${ }^{31} \mathrm{P} \mathrm{NMR}$ spectrum had been published already [9].

\section{Results and Discussion}

\section{Reaction of $\alpha-P_{4} S_{3} I_{2}$ with methylthiirane, and observed products}

The reactions gave homogenous solutions in which relative quantities of phosphorus-containing products were estimated
Since then, we have examined methylthiirane $\mathbf{3}$, as a reagent for sulfurisation of phosphorus, in the presence of $\operatorname{Re}(\mathrm{O}) \mathrm{Cl}_{3}\left(\mathrm{PPh}_{3}\right)_{2}$ as an homogenous sulfur transfer catalyst [4]. This reacted readily at room temperature in solution 
by ${ }^{31} \mathrm{P}$ NMR integration. Because the spectra contained three regions of strongly overlapping multiplets (see below), this method was less accurate than usual, but the qualitative conclusions given here are believed to be correct.

Ratio $\alpha-\mathrm{P}_{4} \mathrm{~S}_{3} \mathrm{I}_{2}: \mathrm{CH}_{3}\left(\mathrm{CHCH}_{2} \mathrm{~S}\right)=1: 2$. Rac-methylthiirane was mixed with a ca. $0.05 \mathrm{~mol} \mathrm{dm}^{-3}$ solution of $\alpha-\mathrm{P}_{4} \mathrm{~S}_{3} \mathrm{I}_{2}$ in $\mathrm{CS}_{2}$. After 22 hours at $21^{\circ} \mathrm{C}$, the visibly unchanged solution contained mostly unreacted $\alpha-\mathrm{P}_{4} \mathrm{~S}_{3} \mathrm{I}_{2}$, along with $\alpha-\mathrm{P}_{4} \mathrm{~S}_{3}\left(\mathrm{SCHMeCH}_{2} \mathrm{I}\right) \mathrm{I}$ and a little $\alpha-\mathrm{P}_{4} \mathrm{~S}_{3}\left(\mathrm{SCHMeCH}_{2} \mathrm{I}\right)_{2}$. Half the solution was then heated under reflux at $60^{\circ} \mathrm{C}$ for 5 hours. The dithiolate $\alpha-\mathrm{P}_{4} \mathrm{~S}_{3}\left(\mathrm{SCHMeCH}_{2} \mathrm{I}\right)_{2}$ was now the major constituent (49 mol\%). Some $\alpha-\mathrm{P}_{4} \mathrm{~S}_{3} \mathrm{I}_{2} \quad(14 \mathrm{~mol} \%) \quad$ and $\alpha-\mathrm{P}_{4} \mathrm{~S}_{3}\left(\mathrm{SCHMeCH}_{2} \mathrm{I}\right) \mathrm{I}(18 \mathrm{~mol} \%)$ remained, and traces of the decomposition products $\alpha-$ and $\beta-P_{4} S_{4}, \alpha-P_{4} S_{5}$ and $P_{4} S_{7}$ had appeared. With hindsight, $\alpha-\mathrm{P}_{4} \mathrm{~S}_{3}(\mathrm{~S})\left(\mathrm{SCHMeCH}_{2} \mathrm{I}\right) \mathrm{I}$ was just detectable. The peaks representing the remaining $19 \mathrm{~mol} \%$ of the major components were assigned hypothetically to the unsymmetric di-insertion product $\alpha-\mathrm{P}_{4} \mathrm{~S}_{3}\left(\mathrm{SCHMeCH}_{2} \mathrm{I}\right)\left(\mathrm{SCH}_{2} \mathrm{CHIMe}\right)$.

Of the methylthiirane taken, $23 \%$ was unaccounted for by the phosphorus-containing products. The statistical distribution $\quad \alpha-\mathrm{P}_{4} \mathrm{~S}_{3} \mathrm{I}_{2}: \quad \alpha-\mathrm{P}_{4} \mathrm{~S}_{3}\left(\mathrm{SCHMeCH}_{2} \mathrm{I}\right) \mathrm{I}$ : $\alpha-\mathrm{P}_{4} \mathrm{~S}_{3}\left(\mathrm{SCHMeCH}_{2} \mathrm{I}\right)_{2}$ for a substituent redistribution reaction is $8: 41: 51$, based on the quantities of iodide and $\mathrm{SCHMeCH}_{2} \mathrm{I}$ ligands found in these compounds. This may be compared with the observed distribution $17: 23: 60$, showing that a redistribution equilibrium probably was not reached. While the related cage compound $\mathrm{P}_{3} \mathrm{Se}_{4} \mathrm{I}$ undergoes a rapid skeletal rearrangement reaction in solution in $\mathrm{CS}_{2}$, involving simultaneous exchange of the exocyclic iodide substituent between phosphorus atoms, no dynamic NMR effects were observed for the corresponding thiolate $\mathrm{P}_{3} \mathrm{Se}_{4}(\mathrm{SEt})$, even at $370 \mathrm{~K}$ [10].

The other half of the original solution was instead treated with ca. 0.05 mole equivalent of $\operatorname{Re}(\mathrm{O}) \mathrm{Cl}_{3}\left(\mathrm{PPh}_{3}\right)_{2}$ (compared with the original methylthiirane content of this portion), giving a dark brown solution, which was stirred at room temperature for 5 hours. The distribution of phosphorus cage compounds was mostly unchanged by this, except that traces of the two diastereomers of $\alpha-\mathrm{P}_{4} \mathrm{~S}_{3}(\mathrm{~S})\left(\mathrm{SCHMeCH}_{2} \mathrm{I}\right) \mathrm{I}$ now were clearly visible, so that their spectra could be fitted (see below).

Ratio $\alpha-P_{4} S_{3} I_{2}: \mathrm{CH}_{3}\left(\mathrm{CHCH}_{2} \mathrm{~S}\right)=1: 1$. In this experiment, double the concentration of $\alpha-\mathrm{P}_{4} \mathrm{~S}_{3} \mathrm{I}_{2}$ was used, to favour the formation of $\alpha-\mathrm{P}_{4} \mathrm{~S}_{3}\left(\mathrm{SCHMeCH}_{2} \mathrm{I}\right) \mathrm{I}$, and, immediately after mixing, the solution was heated to $60^{\circ} \mathrm{C}$ for 23 hours. Under these conditions, $55 \%$ of the methylthiirane taken was unaccounted for by the phosphorus-containing products. The resulting solution contained $\alpha-\mathrm{P}_{4} \mathrm{~S}_{3} \mathrm{I}_{2}$, $\alpha-\mathrm{P}_{4} \mathrm{~S}_{3}\left(\mathrm{SCHMeCH}_{2} \mathrm{I}\right) \mathrm{I}$ and $\alpha-\mathrm{P}_{4} \mathrm{~S}_{3}\left(\mathrm{SCHMeCH}_{2} \mathrm{I}\right)_{2}$ in the ratio 61: 33:6. This was similar to the statistical distribution $60: 35: 5$, so a redistribution equilibrium may have been attained after the longer heating period. The lower concentration of $\alpha-\mathrm{P}_{4} \mathrm{~S}_{3}\left(\mathrm{SCHMeCH}_{2} \mathrm{I}\right)_{2}$ relative to $\alpha-\mathrm{P}_{4} \mathrm{~S}_{3}\left(\mathrm{SCHMeCH}_{2} \mathrm{I}\right) \mathrm{I}$ allowed more of the spectra of the two diastereomers of the thiolate iodide to be revealed, and good computer fits to be obtained.

Ratio $\alpha-\mathrm{P}_{4} \mathrm{~S}_{3} \mathrm{I}_{2}: \mathrm{CH}_{3}\left(\mathrm{CHCH}_{2} \mathrm{~S}\right)=1: 4$. Here, twice as much methylthiirane was taken, compared with the first experiment, and the solution was heated to $60{ }^{\circ} \mathrm{C}$ for 23 hours, with the intention not only of favouring the formation of $\alpha-\mathrm{P}_{4} \mathrm{~S}_{3}\left(\mathrm{SCHMeCH}_{2} \mathrm{I}\right)_{2}$ and the supposed $\alpha-\mathrm{P}_{4} \mathrm{~S}_{3}\left(\mathrm{SCHMeCH}_{2} \mathrm{I}\right)\left(\mathrm{SCH}_{2} \mathrm{CHIMe}\right)$, but of removing $\alpha-P_{4} S_{3} I_{2}$ and the $\alpha-P_{4} S_{3}$ thiolate iodide, in order to give clearer spectra of these dithiolates. Because compounds containing P-I bonds were used up, the resulting solution was pale lemon instead of bright yellow. The ${ }^{31} \mathrm{P}$ NMR spectrum showed no $\alpha-\mathrm{P}_{4} \mathrm{~S}_{3} \mathrm{I}_{2}$ nor $\alpha-\mathrm{P}_{4} \mathrm{~S}_{3}\left(\mathrm{SCHMeCH}_{2} \mathrm{I}\right) \mathrm{I}$ remaining. The two dithiolates $\alpha-\mathrm{P}_{4} \mathrm{~S}_{3}\left(\mathrm{SCHMeCH}_{2} \mathrm{I}\right)_{2}$ and $\alpha-\mathrm{P}_{4} \mathrm{~S}_{3}\left(\mathrm{SCHMeCH}_{2} \mathrm{I}\right)\left(\mathrm{SCH}_{2} \mathrm{CHIMe}\right)$ were found in the ratio $69: 31$, which was similar to the ratio $72: 28$ estimated in the first experiment. The spectra of all three diastereomers of $\alpha-\mathrm{P}_{4} \mathrm{~S}_{3}\left(\mathrm{SCHMeCH} \mathrm{H}_{2} \mathrm{I}\right)_{2}$ could now be fitted, but the four diastereomers of $\alpha-\mathrm{P}_{4} \mathrm{~S}_{3}\left(\mathrm{SCHMeCH}_{2} \mathrm{I}\right)\left(\mathrm{SCH}_{2} \mathrm{CHIMe}\right)$ were seen only as a region of overlapping multiplets corresponding to one of the phosphorus positions. The regions representing the other three of the four phosphorus atoms per diastereomer were too obstructed, by the spectra of the major product, for analysis, so coupling constants could not be obtained and assignment of the minor product to $\alpha-\mathrm{P}_{4} \mathrm{~S}_{3}\left(\mathrm{SCHMeCH}_{2} \mathrm{I}\right)\left(\mathrm{SCH}_{2} \mathrm{CHIMe}\right)$ remains an hypothesis.

The four diastereomers of the monosulfurised dithiolate $\alpha-\mathrm{P}_{4} \mathrm{~S}_{3}(\mathrm{~S})\left(\mathrm{SCHMeCH}_{2} \mathrm{I}\right)_{2}$ were observed to constitute about $7 \mathrm{~mol} \%$ of the measured product. Sets of overlapping multiplets were found for three of the phosphorus atoms, with only one set of multiplets being obscured. While, consequently, these spectra also could not be fitted, the spin systems were almost first order, so approximations could be made to all of the phosphorus NMR parameters, except for one set of chemical shifts, making the identification fairly certain. Addition of a further two molar equivalents of methylthiirane, in case the original excess had now polymerised, and 0.1 molar equivalents of the rhenium catalyst, was found after 8 hours at room temperature to have given further amounts of the same set of isomers of $\alpha-\mathrm{P}_{4} \mathrm{~S}_{3}(\mathrm{~S})\left(\mathrm{SCHMeCH}_{2} \mathrm{I}\right)_{2}$, but also many new overlapping multiplets in the same regions, making analysis of the spectrum too difficult.

\section{Direction of insertion; isomers and diastereomers of products}

Iodine is somewhat more electronegative than phosphorus, on any of the common scales, and attack by a P-I bond on methylthiirane may be thought of as starting with nucleophilic attack, by the partially charged iodine atom, on a ring carbon atom. The LUMO of $\mathrm{CH}_{3}\left(\mathrm{CHCH}_{2} \mathrm{~S}\right)$, calculated at the RHF/3-21G* level, is $\sigma$ antibonding with respect to both $\mathrm{C}-\mathrm{S}$ bonds. The attacking iodine will experience positive electrostatic potential (ESP) at either ring carbon atom, but the $\mathrm{CH}_{2}$ group carries the most accessible lobe of the LUMO. An image of methylthiirane as a space-filling model, with a surface of the LUMO (contour level 0.015) protruding from it, and ESP mapped upon the LUMO (blue and violet positive, green negative), is given in the Electronic Supporting Information (ESI). It may be predicted that iodine will attack the $\mathrm{CH}_{2}$ group, causing heterolytic cleavage of the $\mathrm{CH}_{2}-\mathrm{S}$ bond, and formation of the ...I- $\mathrm{CH}_{2} \mathrm{CH}(\mathrm{Me}) \mathrm{S}^{\delta-}$ pendant group (Scheme 2). Attack by the partially charged sulfur atom on phosphorus will finally cause cleavage of the P-I bond, giving a $\mathrm{SCHMeCH}_{2} \mathrm{I}$ substituent in the major kinetic product. Alternative attack of iodine on the less accessible 
lobe of the LUMO, at the CHMe group, would lead to a $\mathrm{SCH}_{2} \mathrm{CHIMe}$ substituent in a minor kinetic product.

\section{((Insert Scheme 2 here, double column width))}

The further possibility, of initial attack by thiirane sulfur on phosphorus, followed by orientation of the still intact threemembered ring to allow intramolecular attack by the iodine on the $\mathrm{CH}_{2}$ group, seems much less likely because (a) solvent $\mathrm{CS}_{2}$ would compete more effectively with neutral than with negatively charged sulfur for coordination to phosphorus; (b) the concerted mechanism would involve a 4-membered instead of a 5-membered ring; and (c) orientation of the coordinated thiirane, to present a $\sigma^{*}$ orbital at $\mathrm{CH}_{2}$ to the iodine, would be more difficult.

Modelling the products by ab initio methods, at a sufficient level to predict rigorously the more thermodynamically stable, would be a major undertaking because of the number of bond rotamers which should be considered. This is a severe problem for any $\alpha-\mathrm{P}_{4} \mathrm{~S}_{3}$ derivatives which carry exocyclic substituents with several possibilities for internal rotations, as shown recently for amide substituents [11]. Software, which uses force field methods to search automatically for conformers, cannot take account of nonbonded interactions between the substituent conformers and the phosphorus sulfide cage, so searching must be done at an ab initio level and, in our case, set up by hand. Models of one rotamer for each of the two diastereomers of $\alpha-\mathrm{P}_{4} \mathrm{~S}_{3}\left(\mathrm{SCHMeCH}_{2} \mathrm{I}\right) \mathrm{I}$, three diastereomers of $\alpha-\mathrm{P}_{4} \mathrm{~S}_{3}\left(\mathrm{SCHMeCH}_{2} \mathrm{I}\right)_{2}$, four diastereomers of $\alpha-\mathrm{P}_{4} \mathrm{~S}_{3}\left(\mathrm{SCHMeCH}_{2} \mathrm{I}\right)\left(\mathrm{SCH}_{2} \mathrm{CHIMe}\right)$, and for the three diastereomers of $\alpha-\mathrm{P}_{4} \mathrm{~S}_{3}\left(\mathrm{SCH}_{2} \mathrm{CHIMe}\right)_{2}$ were obtained at the RHF/3-21G* level and the geometries refined using the density functional MPW1PW91 method. The basis set used with this consisted of Ahlrichs svp basis on all atoms except iodine, for which $3-21 \mathrm{G}^{*}$ was taken. Rotatable molecular structure diagrams are presented for these models, along with their energies, in the ESI. During the search for conformers, other rotamers of some of the molecules were examined, but the results are not presented because the predicted energies were significantly higher and the set given is believed to be sufficient to give a useful predictive ability.

The $\alpha-P_{4} S_{3}$ cage is chiral, with $\alpha-P_{4} S_{3} I_{2}$ existing (and crystallising) as a racemic mixture of enantiomers $\mathbf{1 a}$ and $\mathbf{1 b}$ These were represented as (SS) and (RR) respectively in our work on chiral amide derivatives [1,2], showing the configurations of the phosphorus atoms $P_{B}$ and $P_{D}$ to which the iodide substituents were attached. Chiralities of substituents were written outside of the parentheses, to the left for substituent $X$ and to the right for $Y$ (Scheme 1). The chirality symbol for phosphorus remained the same when amide replaced iodide. This is not so for replacement of iodide by thiolate, when the (SS) diiodide would give e.g. a thiolate iodide $\mathbf{R}(\mathbf{R S})$ and then a dithiolate $\mathbf{R}(\mathbf{R R}) \mathbf{R}$ or $\mathbf{R}(\mathbf{R R}) \mathbf{S}$, even though the visual shapes at phosphorus do not change. We will therefore use here only (1a) and (1b) to refer to these visual shapes in Scheme 1. Reaction with racemic methylthiirane would give, as the first product, two diastereomers $\mathbf{R}(\mathbf{1 a})$ and $\mathbf{S}(\mathbf{1 a})$ of $\alpha-\mathrm{P}_{4} \mathrm{~S}_{3}\left(\mathrm{SCHMeCH} \mathrm{CH}_{2} \mathrm{I}\right) \mathrm{I}$ or of $\alpha-\mathrm{P}_{4} \mathrm{~S}_{3}\left(\mathrm{SCH}_{2} \mathrm{CHIMe}\right) \mathrm{I}$, along with their enantiomers, indistinguishable from them by NMR, $\mathbf{S}(\mathbf{1 b})$ and $\mathbf{R}(\mathbf{1 b})$ respectively. Each isomer would thus show two overlapping NMR spectra.
Some diastereomeric excess could be formed in the product, caused by a preference for matching (or mismatching) chirality in the rate-determining step of the reaction. As both reagents were racemic, and a pair of enantiomers, e.g. $\mathbf{R}(\mathbf{1 a})$ and $\mathbf{S}(\mathbf{1 b})$ could account for complete use of both reagents, formation of diastereomeric excess does not depend on partial reaction of one racemic compound, as it would for kinetic resolution using an enantiomerically pure resolving agent.

The dithiolates $\alpha-\mathrm{P}_{4} \mathrm{~S}_{3}\left(\mathrm{SCHMeCH}_{2} \mathrm{I}\right)_{2} \quad$ or $\alpha-\mathrm{P}_{4} \mathrm{~S}_{3}\left(\mathrm{SCH}_{2} \mathrm{CHIMe}\right)_{2}$ would be formed as mixtures of the three diastereomers $\mathbf{R}(\mathbf{1 a}) \mathbf{R}, \mathbf{S}(\mathbf{1 a}) \mathbf{S}$ and $\mathbf{R}(\mathbf{1 a}) \mathbf{S}$. If chiral preference on one side of the cage is independent of the chirality of the distant substituent, the unsymmetric diastereomer $\mathbf{R}(\mathbf{1 a}) \mathbf{S}$ should constitute the statistical $50 \%$ of the mixture of diastereomers, with the symmetric diastereomers $\mathbf{R}(\mathbf{1 a}) \mathbf{R}$ and $\mathbf{S}(\mathbf{1 a}) \mathbf{S}$ constituting either more or less than $25 \%$ of the mixture each [2].

If atom labelling in the mixed dithiolate $\alpha-\mathrm{P}_{4} \mathrm{~S}_{3}\left(\mathrm{SCHMeCH}_{2} \mathrm{I}\right)\left(\mathrm{SCH}_{2} \mathrm{CHIMe}\right)$ is as written (Scheme 1, 1, $\mathrm{X}=\mathrm{SCHMeCH}_{2} \mathrm{I}, \mathrm{Y}=\mathrm{SCH}_{2} \mathrm{CHIMe}$ ), either substituent may have matching or mismatching chirality, so there would be four diastereomers $\mathbf{R}(\mathbf{1 a}) \mathbf{R}, \mathbf{S}(\mathbf{1 a}) \mathbf{R}, \mathbf{R}(\mathbf{1 a}) \mathbf{S}$ and $\mathbf{S}(\mathbf{1 a}) \mathbf{S}$ (each as a pair with the corresponding enantiomer).

Taking statistical weightings into account, the ab initio models predict that if equilibrium were reached between all structural isomers of $\alpha-\mathrm{P}_{4} \mathrm{~S}_{3}\left(\mathrm{SCHMeCH}_{2} \mathrm{I}\right)_{2}$, and between all the diastereomers of each of them, the ratio $\alpha-\mathrm{P}_{4} \mathrm{~S}_{3}\left(\mathrm{SCHMeCH}_{2} \mathrm{I}\right)_{2}$ :

$\alpha-\mathrm{P}_{4} \mathrm{~S}_{3}\left(\mathrm{SCHMeCH}_{2} \mathrm{I}\right)\left(\mathrm{SCH}_{2} \mathrm{CHIMe}\right)$ :

$\alpha-\mathrm{P}_{4} \mathrm{~S}_{3}\left(\mathrm{SCH}_{2} \mathrm{CHIMe}\right)_{2}$ would be $11: 37: 52$. The major thermodynamic product would be the minor kinetic product. For the structural isomer $\alpha-\mathrm{P}_{4} \mathrm{~S}_{3}\left(\mathrm{SCH}_{2} \mathrm{CHIMe}\right)_{2}$, the predicted diastereomer ratio was $\mathbf{R}(\mathbf{1 a}) \mathbf{R}: \mathbf{R}(\mathbf{1 a}) \mathbf{S}$ : $\mathbf{S}(\mathbf{1 a}) \mathbf{S}=36: 47: 16$, whereas for $\alpha-\mathrm{P}_{4} \mathrm{~S}_{3}\left(\mathrm{SCHMeCH}_{2} \mathrm{I}\right)_{2}$ it was $30: 48: 22$. Phosphorus NMR spectra for two symmetric diastereomers were observed, and although overlapping peaks precluded their relative integration, the observed relative intensity was much more similar than the $2.22: 1$ predicted for the $\mathrm{SCH}_{2} \mathrm{CHIMe}$ product, and supports their attribution to the kinetic product $\alpha-\mathrm{P}_{4} \mathrm{~S}_{3}\left(\mathrm{SCHMeCH} \mathrm{H}_{2} \mathrm{I}\right)_{2}$. The observed relative amount of the mixed dithiolate $\alpha-\mathrm{P}_{4} \mathrm{~S}_{3}\left(\mathrm{SCHMeCH}_{2} \mathrm{I}\right)\left(\mathrm{SCH}_{2} \mathrm{CHIMe}\right)$ was then much less than predicted. We conclude that isomerisation of the SCHMeCH $\mathrm{H}_{2} \mathrm{I}$ substituent to $\mathrm{SCH}_{2} \mathrm{CHIMe}$ did not reach equilibrium, and that $\alpha-\mathrm{P}_{4} \mathrm{~S}_{3}\left(\mathrm{SCH}_{2} \mathrm{CHIMe}\right)_{2}$ was not observed. The best evidence, that the major product was $\alpha-\mathrm{P}_{4} \mathrm{~S}_{3}\left(\mathrm{SCHMeCH}_{2} \mathrm{I}\right)_{2}$, came from the ${ }^{13} \mathrm{C}$ NMR spectrum and from ${ }^{13} \mathrm{C},{ }^{1} \mathrm{H}$ correlation experiments on the product of the $1: 4$ reaction, described below.

All of these $\alpha-\mathrm{P}_{4} \mathrm{~S}_{3}$ compounds have been assumed to carry exo,exo-substituents, since the NMR parameters, of those whose spectra have been analysed, correspond to the pattern found for previously known exo,exo- $\alpha-\mathrm{P}_{4} \mathrm{~S}_{3}$ compounds, rather than the less common and normally less stable exo,endo- $\alpha-\mathrm{P}_{4} \mathrm{~S}_{3}$ configuration. Inversion at phosphorus on the NMR timescale is not expected. Sulfurisation at $\mathrm{P}_{\mathrm{B}}$, however, could go either with retention or inversion of configuration, as found for sulfurisation of $\alpha-\mathrm{P}_{4} \mathrm{~S}_{3}$ amides [3]. Each such isomer would consist of two diastereomers, $\quad \mathbf{R}(\mathbf{2 a}) \quad$ and $\quad \mathbf{S}(\mathbf{2 a}), \quad$ for $\alpha-\mathrm{P}_{4} \mathrm{~S}_{3}(\mathrm{~S})\left(\mathrm{SCHMeCH}_{2} \mathrm{I}\right) \mathrm{I}$, as in the unsulfurised compound, 
but for $\alpha-\mathrm{P}_{4} \mathrm{~S}_{3}(\mathrm{~S})\left(\mathrm{SCHMeCH}_{2} \mathrm{I}\right)_{2}$ there would now be four, since the $\mathrm{P}_{\mathrm{B}}$ and $\mathrm{P}_{\mathrm{D}}$ sides of the molecule are differentiated, as for $\alpha-\mathrm{P}_{4} \mathrm{~S}_{3}\left(\mathrm{SCHMeCH} \mathrm{SCH}_{2} \mathrm{I}\left(\mathrm{SCH}_{2} \mathrm{CHIMe}\right)\right.$ above.

\section{Assignment of NMR spectra}

${ }^{13}$ C NMR spectra of the product from the $1: 4$ reaction.

Besides singlets due to unreacted methylthiirane $(\delta=29.94$ $(\mathrm{CH}), 26.77\left(\mathrm{CH}_{2}\right)$ and $21.85\left(\mathrm{CH}_{3}\right)[12]$, the ${ }^{13} \mathrm{C}\left\{{ }^{1} \mathrm{H}\right\}$ spectrum showed major multiplets at $\delta=45.37,22.74$ and 13.41, shown by comparison with the proton-coupled spectrum and a DEPT experiment to be due to $\mathrm{CH}\left({ }^{1} \mathrm{~J}_{\mathrm{CH}}=\right.$ $146 \mathrm{~Hz}), \mathrm{CH}_{3}(128 \mathrm{~Hz})$ and $\mathrm{CH}_{2}(152 \mathrm{~Hz})$ respectively. Each of these appeared as four peaks, corresponding to one diastereomeric splitting and one related to ${ }^{13} \mathrm{C}-{ }^{31} \mathrm{P}$ coupling, except for the multiplet due to $\mathrm{CH}$, which showed an extra small doublet splitting of ca. $3 \mathrm{~Hz}$, associated with longer range ${ }^{13} \mathrm{C}-{ }^{31} \mathrm{P}$ couplings. The main splittings were assigned to diastereomeric shift difference, rather than to the coupling to phosphorus, if they were between doublets which were more different in intensity, resulting in the following parameters for $\alpha-\mathrm{P}_{4} \mathrm{~S}_{3}\left(\mathrm{SCHMeCH} \mathrm{S}_{2} \mathrm{I}\right)_{2}$. Diastereomeric shift $(\delta \delta)$ is given as $\delta$ (major diastereomer) - $\delta$ (minor diastereomer). $\mathrm{CH}$ doublet 18.6 (major), 19.7 (minor) $\mathrm{Hz}$ $\delta \delta-24.3 \mathrm{~Hz},-0.19 \mathrm{ppm} ; \mathrm{CH}_{3}$ doublet 4.7 (major), 5.2 (minor) $\mathrm{Hz}, \delta \delta 25.1 \mathrm{~Hz}, 0.20 \mathrm{ppm} ; \mathrm{CH}_{2}$ doublet 6.7 (major), 5.7 (minor) Hz, $\delta \delta 29.5 \mathrm{~Hz}, 0.23 \mathrm{ppm}$. The doublets for the $\mathrm{CH}_{3}$ group were practically equal in height, so the minor/major assignment was less certain than for the other groups.

These results may be explained if carbon-phosphorus couplings and carbon diastereomeric shifts depended only on the chirality match or mismatch between the substituent and the cage phosphorus atom to which it was attached, rather than on any interaction between the two substituents. Thus, e.g., diastereomer $\mathbf{R}(\mathbf{1 a}) \mathbf{S}$ of $\alpha-\mathrm{P}_{4} \mathrm{~S}_{3}\left(\mathrm{SCHMeCH}_{2} \mathrm{I}\right)_{2}$ would show a separate ${ }^{13} \mathrm{C}$ NMR spectrum for each of its substituents, but one of these would be superimposed on that for diastereomer $\mathbf{R}(\mathbf{1 a}) \mathbf{R}$, and the other on that for diastereomer $\mathbf{S}(\mathbf{1 a}) \mathbf{S}$.

The order of chemical shifts between the multiplets was as might be expected for the connectivity P-S-CH$\left(\mathrm{CH}_{3}\right) \mathrm{CH}_{2} \mathrm{I}$. $\mathrm{CH}$ next to sulfur is moved to high frequency: e.g. $\mathrm{CH}$ in $(\mathrm{Et}(\mathrm{Me}) \mathrm{CHS})_{2}$ has $\delta 48.28$, while $\mathrm{CH}$ bonded to iodine would have been moved to low frequency, as in $\mathrm{Et}(\mathrm{Me}) \mathrm{CHI}$ $(\delta 28.5)[12]$.

Table 1 NMR parameters for exo,exo- $\alpha-\mathrm{P}_{4} \mathrm{~S}_{3} \mathrm{XY} 1$ and $\alpha-\mathrm{P}_{4} \mathrm{~S}_{3}(\mathrm{~S}) \mathrm{XY} 2$ in solution in $\mathrm{CS}_{2}$

\begin{tabular}{llllllll}
\hline & $\mathbf{1}$ & $\mathbf{1}$ & $\mathbf{1}$ & $\mathbf{1}$ & $\mathbf{1}$ & $\mathbf{2}$ & $\mathbf{2}$ \\
$\left.\mathrm{X}^{\mathrm{a}}\right)$ & $\mathrm{SR}$ & $\mathrm{SR}$ & $\mathrm{SR}$ & $\mathrm{SR}$ & $\mathrm{SR}$ & $\mathrm{SR}$ & $\mathrm{SR}$ \\
$\left.\mathrm{Y}^{\mathrm{a}}\right)$ & $\mathrm{I}$ & $\mathrm{I}$ & $\mathrm{SR}$ & $\mathrm{SR}$ & $\mathrm{SR}$ & $\mathrm{I}$ & $\mathrm{I}$ \\
Diastereomer & $\mathrm{A}$ & $\mathrm{B}$ & $\mathrm{A}$ & $\mathrm{B}$ & $\mathrm{C}$ & $\mathrm{X}$ & $\mathrm{Y}$ \\
\hline \multicolumn{2}{l}{ (a) Coupling constants $\left.(\mathrm{Hz})^{\mathrm{b}}\right)$} & & & & & & \\
${ }^{1} J\left(\mathrm{P}_{\mathrm{A}} \mathrm{P}_{\mathrm{B}}\right)$ & $-289.0(2)$ & $-290.44(9)$ & $-288.1(5)$ & $-289.8(5)$ & $-287.39(3)$ & $-377.73(2)$ & $-378.43(3)$ \\
${ }^{1} J\left(\mathrm{P}_{\mathrm{C}} \mathrm{P}_{\mathrm{D}}\right)$ & $-242.2(1)$ & $-241.99(8)$ & $-288.1(5)$ & $-289.8(5)$ & $-289.09(5)$ & $-228.76(2)$ & $-229.99(4)$ \\
${ }^{2} J\left(\mathrm{P}_{\mathrm{A}} \mathrm{P}_{\mathrm{C}}\right)$ & $67.1(1)$ & $66.9(1)$ & $59.2(7)$ & $58.0(8)$ & $60.39(4)$ & $71.86(1)$ & $71.47(2)$ \\
${ }^{2} J\left(\mathrm{P}_{\mathrm{A}} \mathrm{P}_{\mathrm{D}}\right)$ & $17.7(2)$ & $18.1(1)$ & $23.0(4)$ & $22.6(5)$ & $22.09(3)$ & $33.98(1)$ & $34.39(3)$ \\
${ }^{2} J\left(\mathrm{P}_{\mathrm{B}} \mathrm{P}_{\mathrm{C}}\right)$ & $24.9(1)$ & $24.74(8)$ & $23.0(4)$ & $22.6(5)$ & $22.25(3)$ & $9.02(2)$ & $8.75(4)$ \\
${ }^{3} J\left(\mathrm{P}_{\mathrm{B}} \mathrm{P}_{\mathrm{D}}\right)$ & $-1.1(1)$ & $-1.0(1)$ & $-8.5(12)$ & $-8.5(15)$ & $-8.20(3)$ & $9.19(3)$ & $9.47(5)$
\end{tabular}

There was one other, smaller multiplet in the ${ }^{13} \mathrm{C}\left\{{ }^{1} \mathrm{H}\right\}$ spectrum, which could be assigned to $\mathrm{CH}_{2}$ of the $\mathrm{SCH}_{2} \mathrm{CHIMe}$ group in the minor product $\alpha-\mathrm{P}_{4} \mathrm{~S}_{3}\left(\mathrm{SCHMeCH}_{2} \mathrm{I}\right)\left(\mathrm{SCH}_{2} \mathrm{CHIMe}\right)$. This was at $\delta 46.75$. $\mathrm{CH}_{2} \mathrm{~S}$ in $\left(\operatorname{Pr}^{\mathrm{n}} \mathrm{S}\right)_{2}$ has $\delta 41.21$ [12]. The DEPT and protoncoupled experiments confirmed that this was a $\mathrm{CH}_{2}$ group, though the intensity was too low for ${ }^{1} \mathrm{~J}_{\mathrm{CH}}$ to be measured. The ${ }^{13} \mathrm{C}\left\{{ }^{1} \mathrm{H}\right\}$ multiplet showed major and minor doublets more different from each other in intensity than for the $\mathrm{SCHMeCH}_{2} \mathrm{I}$ multiplets, as predicted by the ab initio energy calculations (see above). The doublet splitting was ca. $22.2 \mathrm{~Hz}$ for each diastereomer; $\delta \delta$ was $6.2 \mathrm{~Hz}$, $0.05 \mathrm{ppm}$. The remaining, $\mathrm{CH}$ and $\mathrm{CH}_{3}$, multiplets for this substituent were not found.

\section{${ }^{31} P\left\{{ }^{1} H\right\}$ spectra.}

An initial exploration was made using a homonuclear ${ }^{31} \mathrm{P}$ COSY measurement, on the product of the $1: 2$ reaction after heating (see above). Dense regions of peaks were centred at ca. (i) 126; (ii) 121; (iii) 116 and (iv) $104 \mathrm{ppm}$. There were strong correlation peaks for $\alpha-\mathrm{P}_{4} \mathrm{~S}_{3} \mathrm{I}_{2}$ within region (i) and for $\alpha-\mathrm{P}_{4} \mathrm{~S}_{3}\left(\mathrm{SCHMeCH} \mathrm{SH}_{2}\right)_{2}$ between regions (iii) and (iv). One set of correlation peaks in region (i) could be distinguished by position from those of $\alpha-\mathrm{P}_{4} \mathrm{~S}_{3} \mathrm{I}_{2}$, and showed $\alpha-\mathrm{P}_{4} \mathrm{~S}_{3}\left(\mathrm{SCHMeCH}_{2} \mathrm{I}\right) \mathrm{I}$ in regions (i), (ii) and (iii), but not in (iv). There were correlation peaks to the same part of region (iii), from regions (i) and (ii), but no correlation peak could be found between regions (i) $\left(\mathrm{P}_{\mathrm{D}}\right)$ and (ii) $\left(\mathrm{P}_{\mathrm{B}}\right)$. This was because the corresponding coupling for $\alpha-\mathrm{P}_{4} \mathrm{~S}_{3}\left(\mathrm{SCHMeCH}_{2} \mathrm{I}\right) \mathrm{I},{ }^{3} J\left(\mathrm{P}_{\mathrm{B}} \mathrm{P}_{\mathrm{D}}\right)$, was very small $(-1 \mathrm{~Hz}$, Table 1). A third set of correlation peaks in region (i) linked it to region (iv), and were attributed to $\alpha-\mathrm{P}_{4} \mathrm{~S}_{3}\left(\mathrm{SCHMeCH}_{2} \mathrm{I}\right)\left(\mathrm{SCH}_{2} \mathrm{CHIMe}\right)$, for which the $\mathrm{P}_{\mathrm{D}}$ multiplets were found in region (i) of the product of the $1: 4$ reaction, and the $\mathrm{P}_{\mathrm{A}}, \mathrm{P}_{\mathrm{C}}$ multiplets were believed as a result of the present COSY experiment to be in region (iv). There were small correlation peaks for this compound between regions (i) and (iii), where $\mathrm{P}_{\mathrm{B}}$ probably was located. ${ }^{3} J\left(\mathrm{P}_{\mathrm{B}} \mathrm{P}_{\mathrm{D}}\right)$ is expected to be small (c.f. $-8.2 \mathrm{~Hz}$ in diastereomer $\mathbf{R}(\mathbf{1 a}) \mathbf{S}$ of $\left.\alpha-\mathrm{P}_{4} \mathrm{~S}_{3}\left(\mathrm{SCHMeCH}_{2} \mathrm{I}\right)_{2}\right)$, but not as small as in $\alpha-\mathrm{P}_{4} \mathrm{~S}_{3}\left(\mathrm{SCHMeCH}_{2} \mathrm{I}\right) \mathrm{I}$.

Hand analysis of ${ }^{31} \mathrm{P}\left\{{ }^{1} \mathrm{H}\right\}$ spectra was followed by iterative fitting using NUMARIT [13], wherever sufficient peaks could be assigned. In those cases, chemical shifts and coupling constants are given in Table 1. 
${ }^{31} \mathrm{P}\left\{{ }^{1} \mathrm{H}\right\} \quad \mathrm{NMR}$ spectra of $\alpha-\mathrm{P}_{4} \mathrm{~S}_{3}\left(\mathrm{SCHMeCH}_{2} \mathrm{I}\right) \mathrm{I}$ (1, X= (SCHMeCH $\mathrm{SH}_{2}$ ), $\mathrm{Y}=\mathrm{I}$ ).

The smallest chemical shift difference was $\delta\left(\mathrm{P}_{\mathrm{A}}\right)-\delta\left(\mathrm{P}_{\mathrm{C}}\right)$ (Scheme 1), which was $2.87 \mathrm{ppm}$ for diastereomer $\mathrm{A}$ and $1.84 \mathrm{ppm}$ for diastereomer B. The coupling ${ }^{2} J\left(\mathrm{P}_{\mathrm{A}} \mathrm{P}_{\mathrm{C}}\right)$ was 67.1 and $66.9 \mathrm{~Hz}$ respectively, giving $J / \delta=0.115$ at 202.5 MHz for diastereomer A. This was sufficiently small that all four phosphorus atoms gave strongly tented but simple multiplets which could be analysed using the first order approximation, to provide a starting point for a Numarit fit. Diastereomer B had $J / \delta=0.179$, giving multiplets which could not be analysed in this way, but, by assuming the same couplings as in diastereomer $\mathrm{A}$ and estimating the differences in chemical shifts from it, a recognisable simulation was obtained. The chemical shifts and coupling constants (Table 1 ) were very similar to those for $\alpha-\mathrm{P}_{4} \mathrm{~S}_{3}(\mathrm{SPh}) \mathrm{I}$ [9]. The $\mathrm{P}_{\mathrm{D}}$ multiplet could be assigned relative to $\mathrm{P}_{\mathrm{B}}$, because ${ }^{1} J\left(\mathrm{P}_{\mathrm{C}} \mathrm{P}_{\mathrm{D}}\right)$ had a value less negative than ${ }^{1} J\left(\mathrm{P}_{\mathrm{A}} \mathrm{P}_{\mathrm{B}}\right)$, typical for $\alpha-\mathrm{P}_{4} \mathrm{~S}_{3}$ compounds with iodine attached to $\mathrm{P}_{\mathrm{D}}$.

The peaks assigned to $P_{B}$ were sufficiently free of overlaps for integration, giving the diastereomer ratio $\mathrm{A}: \mathrm{B}=1.19: 1$. The ratio $\mathbf{R}(\mathbf{1 a}): \mathbf{S}(\mathbf{1 a})$ was predicted at the ab initio MPW1PW91/svp level to be 1.09 : 1 (see ESI), suggesting that diastereomer A was $\mathbf{R}(\mathbf{1 a})$. The largest diastereomeric difference in P-P coupling constants, for ${ }^{1} J\left(\mathrm{P}_{\mathrm{A}} \mathrm{P}_{\mathrm{B}}\right)$, was small $(1.4 \mathrm{~Hz})$, but its sign was in agreement with the ab initio prediction that diastereomer $\mathbf{R}(\mathbf{1 a})$ had the longer $\mathrm{P}_{\mathrm{A}}-\mathrm{P}_{\mathrm{B}}$ bond (by $0.0017 \AA$ ), and so might be expected to have the less negative ${ }^{1} J$ coupling constant, as observed for diastereomer A. The longer predicted bond may be associated with a torsion angle C-S $-\mathrm{P}_{\mathrm{B}}-\mathrm{P}_{\mathrm{A}}$ nearer to $90^{\circ}$, allowing more $\Pi$ interaction between a thiolate sulfur 'lone pair' and the $\sigma^{*} \mathrm{P}_{\mathrm{B}}-\mathrm{P}_{\mathrm{A}}$ orbital. Previously we have demonstrated a similar connection between observed ${ }^{1} J\left(\mathrm{P}_{\mathrm{A}} \mathrm{P}_{\mathrm{B}}\right)$ and calculated torsion angle to the mean bonding plane of nitrogen in bond rotamers of an amide [2, 14], where the differences, both in coupling constant and in torsion angle, were much larger than in the present case.
${ }^{31} \mathrm{P}\left\{{ }^{1} \mathrm{H}\right\} \mathrm{NMR}$ spectra of $\alpha-\mathrm{P}_{4} \mathrm{~S}_{3}\left(\mathrm{SCHMeCH}_{2} \mathrm{I}\right)_{2}(\mathrm{I}, \mathrm{X}=\mathrm{Y}=$ ( $\mathrm{SCHMeCH} \mathrm{CH}_{2}$.

At $202.5 \mathrm{MHz}$, a number of sharp peaks for the unsymmetric diastereomer $\mathbf{R}(\mathbf{1 a}) \mathbf{S}$ could be distinguished from the typical $\mathrm{AA}^{\prime} \mathrm{MM}^{\prime}$ spectra of the symmetric diastereomers $\mathbf{R}(\mathbf{1 a}) \mathbf{R}$ and $\mathbf{S}(\mathbf{1 a}) \mathbf{S}$, which had rather broader peaks containing more overlapping transitions. Since assignments to absolute configuration are only hypotheses in this work, the symmetric diastereomers are referred to experimentally as $\mathrm{A}$ and $\mathrm{B}$, in order of relative abundance, and the unsymmetric diastereomer as $\mathrm{C}$, as in previous work [2].

Diastereomer $C$. This had an internal diastereomeric shift $\delta\left(\mathrm{P}_{\mathrm{A}}\right)-\delta\left(\mathrm{P}_{\mathrm{C}}\right)$ of $1.22 \mathrm{ppm}$, and a coupling constant ${ }^{2} J\left(\mathrm{P}_{\mathrm{A}} \mathrm{P}_{\mathrm{C}}\right)$ of $60.4 \mathrm{~Hz}$, giving $J / \delta 0.244$ at $202.5 \mathrm{MHz}$. In contrast, although $\delta\left(\mathrm{P}_{\mathrm{B}}\right)-\delta\left(\mathrm{P}_{\mathrm{D}}\right)$ was only $0.33 \mathrm{ppm}, \quad{ }^{3} J\left(\mathrm{P}_{\mathrm{B}} \mathrm{P}_{\mathrm{D}}\right)$ was -8.20 , so the corresponding $|J / \delta|$ was only 0.122 . The spin system could be analysed as AFMN and the MN region $\left(\mathrm{P}_{\mathrm{A}}\right.$ and $\mathrm{P}_{\mathrm{C}}$, region (iv), above) treated by subspectral analysis. This region was recognised because the outermost four peaks on each side showed the typical separations of half of a bridgehead phosphorus multiplet in a $\alpha-\mathrm{P}_{4} \mathrm{~S}_{3}$ compound. The hand analysis yielded all of the coupling constants except for ${ }^{3} J\left(\mathrm{P}_{\mathrm{B}} \mathrm{P}_{\mathrm{D}}\right)$, along with $\delta\left(\mathrm{P}_{\mathrm{A}}\right)$ and $\delta\left(\mathrm{P}_{\mathrm{C}}\right)$. An initial value of $-8 \mathrm{~Hz}$ was taken for ${ }^{3} J\left(\mathrm{P}_{\mathrm{B}} \mathrm{P}_{\mathrm{D}}\right)$, by analogy with $\alpha-\mathrm{P}_{4} \mathrm{~S}_{3}(\mathrm{SEt})_{2}$, and the diastereomeric shift $\delta\left(\mathrm{P}_{\mathrm{B}}\right)-\delta\left(\mathrm{P}_{\mathrm{D}}\right)$ was found by trial and error simulations until one could be recognised and the spectrum fitted. The resulting shifts were translated to an operating frequency of $121.5 \mathrm{~Hz}$, allowing a spectrum at this lower field strength also to be recognised and fitted, confirming the assignment of peaks in both cases.

Diastereomers $A$ and $B$. For each diastereomer, each multiplet $\left(\left(\mathrm{P}_{\mathrm{B}}, \mathrm{P}_{\mathrm{D}}\right)\right.$, region (iii), and $\left(\mathrm{P}_{\mathrm{A}}, \mathrm{P}_{\mathrm{C}}\right)$, region (iv)) is expected to consist of two strong peaks and two $\mathrm{AB}$ subspectra. At $202.5 \mathrm{MHz}$ in region (iv), the two strong peaks separated by $N\left(={ }^{1} J\left(\mathrm{P}_{\mathrm{A}} \mathrm{P}_{\mathrm{B}}\right)+{ }^{2} J\left(\mathrm{P}_{\mathrm{B}} \mathrm{P}_{\mathrm{C}}\right)\right)$ were resolved for each diastereomer. Diastereomer $\mathrm{A}$, at higher shift $\delta\left(\mathrm{P}_{\mathrm{A}}\right)$, had measurably smaller $|N|$ (by $2.1 \mathrm{~Hz}$ ), allowing the higher frequency spectrum in region (iii) also to be assigned to diastereomer A, even though the relative abundance could not be seen there, because of overlapping peaks. Coupling constants found for $\alpha-\mathrm{P}_{4} \mathrm{~S}_{3}\left(\mathrm{SCHMeCH} \mathrm{SH}_{2} \mathrm{I}\right) \mathrm{I}$ and for $\alpha-\mathrm{P}_{4} \mathrm{~S}_{3} \mathrm{I}_{2}$ were then used to predict couplings for $\alpha-\mathrm{P}_{4} \mathrm{~S}_{3}\left(\mathrm{SCHMeCH}_{2} \mathrm{I}\right)_{2}$, by means of our 'balancing rules' [2]. Numarit simulations from these allowed enough peaks of each diastereomer to be identified, for the spectra to be fitted. The diastereomeric shifts $\delta\left(\mathrm{P}_{\mathrm{B}}\right)-\delta\left(\mathrm{P}_{\mathrm{D}}\right)$ and particularly $\delta\left(\mathrm{P}_{\mathrm{A}}\right)-\delta\left(\mathrm{P}_{\mathrm{C}}\right)$ were larger within diastereomer $\mathrm{C}$ than between diastereomers $\mathrm{A}$ and $\mathrm{B}$.

Higher abundance, higher chemical shifts, less negative ${ }^{1} J\left(\mathrm{P}_{\mathrm{A}} \mathrm{P}_{\mathrm{B}}\right)$ and more positive ${ }^{2} J\left(\mathrm{P}_{\mathrm{B}} \mathrm{P}_{\mathrm{C}}\right)$ (giving smaller $|N|$ ) suggested that diastereomer $\mathrm{A}$ had the same chirality match, 
between cage and substituent, as diastereomer $\mathrm{A}$ of $\alpha-\mathrm{P}_{4} \mathrm{~S}_{3}\left(\mathrm{SCHMeCH}_{2} \mathrm{I}\right) \mathrm{I}$. The ab initio calculations predicted that the more stable diastereomer $\mathbf{R}(\mathbf{1 a}) \mathbf{R}$ would have, as for $\alpha-\mathrm{P}_{4} \mathrm{~S}_{3}\left(\mathrm{SCHMeCH}_{2} \mathrm{I}\right) \mathrm{I}$, a longer bond $\mathrm{P}_{\mathrm{A}}-\mathrm{P}_{\mathrm{B}}$ and a smaller torsion angle $\mathrm{C}-\mathrm{S}-\mathrm{P}_{\mathrm{B}}-\mathrm{P}_{\mathrm{A}}$. Probably diastereomer $\mathrm{A}$ was $\mathbf{R}(\mathbf{1 a}) \mathbf{R}$ and diastereomer $\mathrm{B}$ was $\mathbf{S}(\mathbf{1 a}) \mathbf{S}$. In diastereomer $\mathrm{C}$, the side of the molecule with the less negative ${ }^{1} J\left(\mathrm{P}_{\mathrm{A}} \mathrm{P}_{\mathrm{B}}\right)$ and the higher chemical shifts $\delta\left(\mathrm{P}_{\mathrm{A}}\right)$ and $\delta\left(\mathrm{P}_{\mathrm{B}}\right)$, probably carried the $\mathrm{R}$ chirality substituent, so writing the chirality as $\mathbf{R}(\mathbf{1 a}) \mathbf{S}$ rather than as $\mathbf{S}(\mathbf{1 a}) \mathbf{R}$, would be correct in terms of the atom labelling in Scheme 1 and the NMR parameter labelling in Table 1 . The ab initio calculations predicted that $\mathrm{P}_{\mathrm{A}}-\mathrm{P}_{\mathrm{B}}$ in $\mathbf{R}(\mathbf{1 a}) \mathbf{S}$ is longer than $\mathrm{P}_{\mathrm{C}}-\mathrm{P}_{\mathrm{D}}$, by $0.0019 \AA$.

\section{${ }^{31} \mathrm{P}\left\{{ }^{1} \mathrm{H}\right\} \quad \mathrm{NMR} \quad$ spectra of $\quad \alpha-\mathrm{P}_{4} \mathrm{~S}_{3}\left(\mathrm{SCHMeCH}_{2} \mathrm{I}\right)$ $\left(\mathrm{SCH}_{2} \mathrm{CHIMe}\right)$}

The group of peaks in region (i) of the spectrum of the $1: 4$ product, attributed to $\mathrm{P}_{\mathrm{D}}$ as a result of the COSY experiment (above), were not individually assigned because of lack of enough information on chemical shifts to provide a recognisable simulation for any of the diastereomers. The appearance of the simulated $\mathrm{P}_{\mathrm{D}}$ multiplet depended particularly strongly on the internal chemical shift $\delta\left(\mathrm{P}_{\mathrm{A}}\right)-\delta\left(\mathrm{P}_{\mathrm{C}}\right)$. The statistically weighted predicted relative abundances of the diastereomers was $43: 19: 13: 25$, in the order given in the ESI. It would have been possible for the observed group of peaks to have consisted of one major spectrum and other, progressively more minor spectra, but probably not to have been made up of several components of similar intensity. The chemical shift $\delta\left(\mathrm{P}_{\mathrm{D}}\right)$ was ca. $126.1 \mathrm{ppm}$.

\section{${ }^{31} \mathrm{P}\left\{{ }^{1} \mathrm{H}\right\} \quad \mathrm{NMR}$ spectra of $\alpha-\mathrm{P}_{4} \mathrm{~S}_{3}(\mathrm{~S})\left(\mathrm{SCHMeCH} \mathrm{CH}_{2} \mathrm{I}\right) \mathrm{I}$ $\left.X=\left(\mathrm{SCHMeCH}_{2} \mathrm{I}\right), \mathrm{Y}=\mathrm{I}\right)$}

These nearly first order spectra were recognised from the high chemical shifts of the $\mathrm{P}_{\mathrm{B}}$ multiplets $(162.8 \mathrm{ppm}$, Table 1) and low chemical shifts of $P_{A}(68.8 \mathrm{ppm})$, which made them appear in relatively clear regions of the spectral range. The high and low shifts are characteristic of addition of a terminal sulfur atom at $\mathrm{P}_{\mathrm{B}}$, as is the large coupling they share [3]. The $\mathrm{P}_{C}$ and $\mathrm{P}_{\mathrm{D}}$ multiplets could then be identified as sharing other couplings with $\mathrm{P}_{\mathrm{A}}$ or $\mathrm{P}_{\mathrm{B}}$. The spectra could be distinguished from those of other sulfurisation products because their intensities varied together over several product mixtures, and clearly represented two diastereomers, as required for one the stereoisomers of $\alpha-\mathrm{P}_{4} \mathrm{~S}_{3}(\mathrm{~S})\left(\mathrm{SCHMeCH}_{2} \mathrm{I}\right) \mathrm{I}$, rather than the four diastereomers of $\alpha-\mathrm{P}_{4} \mathrm{~S}_{3}(\mathrm{~S})\left(\mathrm{SCHMeCH}_{2} \mathrm{I}\right)_{2}$, which also were present in some of the mixtures (see below).

The two diastereomers were of similar abundance. To avoid implying a correspondence with the configurations of diastereomers $\mathrm{A}$ and $\mathrm{B}$ of $\alpha-\mathrm{P}_{4} \mathrm{~S}_{3}\left(\mathrm{SCHMeCH}_{2} \mathrm{I}\right) \mathrm{I}$, we refer to the present pair as $\mathrm{X}$ and $\mathrm{Y}$. For $\mathrm{P}_{\mathrm{B}}$, the diastereomeric shift $\delta \delta$ was $-0.08 \mathrm{ppm}$, or $-10 \mathrm{~Hz}$ at $121.5 \mathrm{MHz}$. Both ${ }^{2} J\left(\mathrm{P}_{\mathrm{B}} \mathrm{P}_{\mathrm{C}}\right)$ and ${ }^{2} J\left(\mathrm{P}_{\mathrm{B}} \mathrm{P}_{\mathrm{D}}\right)$ had values of ca. $9 \mathrm{~Hz}$, so the $\mathrm{P}_{\mathrm{B}}$ multiplets together appeared at this operating frequency as a doublet $\left({ }^{1} J\left(\mathrm{P}_{\mathrm{A}} \mathrm{P}_{\mathrm{B}}\right)\right)$ of quartets. The diastereomeric shifts for $\mathrm{P}_{\mathrm{D}}$ and $\mathrm{P}_{\mathrm{A}}$ were larger, so that the diastereomer multiplets were interleaved, while $\delta \delta$ was exceptionally large for $\mathrm{P}_{\mathrm{C}}$ $(-3.87 \mathrm{ppm})$, giving separate multiplets. In a $\alpha-\mathrm{P}_{4} \mathrm{~S}_{3}$ amide iodide $(1, \mathrm{X}=\mathrm{NHCH}(\mathrm{Me}) \mathrm{Ph}, \mathrm{Y}=\mathrm{I})$, it was $\mathrm{P}_{\mathrm{D}}$, carrying the iodide substituent, which showed the greatest diastereomeric shift (2.98 ppm) [1]. Diastereomeric differences in coupling constants were small, making it difficult to determine which of the two multiplets in each region belonged to a particular diastereomer. Evidence for this association was sought by trial and error fits, interchanging the assignment in each region in turn. The best fits are presented in Table 1 , but the results are not certain: i.e. the sign of at least one of the diastereomeric shifts might be the opposite.

The distribution of chemical shifts and coupling constants parallels that for either invertomer of $\alpha-\mathrm{P}_{4} \mathrm{~S}_{3}(\mathrm{~S})\left(\mathrm{NPr}_{2}{ }_{2}\right)_{2}(2$, $\mathrm{X}=\mathrm{Y}=\mathrm{NPr}_{2}^{\mathrm{i}}$ ) [3], either with the 1-coordinate sulfur endo to the cage or exo to it. The compounds are sufficiently dissimilar that an assignment to one rather than the other stereochemistry cannot be made by this analogy. Sulfurisation of the diamino compound gave the stereoisomers in about 3:1 ratio, whereas in the present experiments only one such isomer was identified. Comparing $\quad \alpha-\mathrm{P}_{4} \mathrm{~S}_{3}(\mathrm{~S})\left(\mathrm{SCHMeCH}_{2} \mathrm{I}\right) \mathrm{I} \quad$ with $\alpha-\mathrm{P}_{4} \mathrm{~S}_{3}\left(\mathrm{SCHMeCH}_{2} \mathrm{I}\right) \mathrm{I}$, each of the four chemical shifts changed on sulfurisation in the same direction and with a similar magnitude of change to those in the $\alpha-\mathrm{P}_{4} \mathrm{~S}_{3}(\mathrm{~S})\left(\mathrm{NPr}_{2}{ }_{2}\right)_{2}$ case. The three coupling constants to $\mathrm{P}_{\mathrm{A}}$ changed in the same directions, but ${ }^{1} J\left(\mathrm{P}_{\mathrm{A}} \mathrm{P}_{\mathrm{B}}\right)$ became more negative by a larger amount $(88.7 \mathrm{~Hz})$ than did the corresponding coupling in $\alpha-\mathrm{P}_{4} \mathrm{~S}_{3}(\mathrm{~S})\left(\mathrm{NPr}_{2}{ }_{2}\right)_{2}(21.9 \mathrm{~Hz})$. For the analogous $\alpha-\mathrm{P}_{4} \mathrm{~S}_{3}(\mathrm{~S})(\mathrm{NMePh})_{2}$, the change was $41.6 \mathrm{~Hz}$ [3]. Probably the greater $\Pi$ to $\sigma^{*}$ donor ability of the amide substituents, particularly $\mathrm{NPr}_{2}{ }_{2}$, caused a weakening of the $\mathrm{P}_{\mathrm{A}}-\mathrm{P}_{\mathrm{B}}$ bond to compensate for the other effects of increasing oxidation state of $\mathrm{P}_{B}$ on sulfurisation. In $\alpha-\mathrm{P}_{4} \mathrm{~S}_{5}$, where there are no exocyclic substituents except for one 1-coordinate sulfur atom, the difference in ${ }^{1} J$ coupling constants, comparing otherwise identical P-P and $\mathrm{P}-\mathrm{P}(\mathrm{S})$ bonds, is $100 \mathrm{~Hz}$.

$\left.{ }^{31} \mathrm{P}^{1}{ }^{1} \mathrm{H}\right\} \mathrm{NMR}$ spectra of $\alpha-\mathrm{P}_{4} \mathrm{~S}_{3}(\mathrm{~S})\left(\mathrm{SCHMeCH}_{2} \mathrm{I}\right)_{2} \quad(2, \mathrm{X}=$ $\left.Y=\left(\mathrm{SCHMeCH}_{2} \mathrm{I}\right)\right)$

Because the $P_{D}$ signals of this compound were obscured by those of other compounds in the reaction mixtures, useful computer fits to the other three multiplets of each diastereomer were not possible. The best available approximations to coupling constants were the corresponding splittings, averaged where more than one instance of the splitting was observed. The accuracy obtainable in this way was too low, compared with the small diastereomeric differences in couplings, for one of the four multiplets in each region to be assigned to the same particular diastereomer. This association also could not be made on the basis of comparisons of diastereomeric differences in chemical shifts, with corresponding differences assigned for $\alpha-\mathrm{P}_{4} \mathrm{~S}_{3}(\mathrm{~S})\left(\mathrm{SCHMeCH}_{2} \mathrm{I}\right) \mathrm{I}$, where these existed. Only some were similar. The four diastereomers were of approximately the same abundance, so relative peak heights gave no further information.

Phosphorus $\mathrm{P}_{\mathrm{A}}$ gave well resolved, interleaved, eight-line multiplets for all four diastereomers. The six differences in chemical shifts included two similar pairs, assigned to diastereomeric shifts $\delta \delta\left(\mathrm{P}_{\mathrm{A}}\right) \quad(1.866, \quad 1.862, \quad 0.209$, $0.205 \mathrm{ppm})$. One pair was caused by differing chirality of the thiolate $\mathrm{X}$, and the other by $\mathrm{Y}$. 
The $\mathrm{P}_{\mathrm{B}}$ region consisted of two interleaved doublets $\left({ }^{1} J\left(\mathrm{P}_{\mathrm{A}} \mathrm{P}_{\mathrm{B}}\right)\right)$ of quartets, where the quartet splitting was caused by near correspondence of ${ }^{2} J\left(\mathrm{P}_{\mathrm{B}} \mathrm{P}_{\mathrm{C}}\right),{ }^{3} J\left(\mathrm{P}_{\mathrm{B}} \mathrm{P}_{\mathrm{D}}\right)$, and the smaller pair of diastereomeric shifts $\delta \delta\left(\mathrm{P}_{\mathrm{B}}\right)$. Neither coupling was available separately from other multiplets. The average value of these three splittings was $8.5 \mathrm{~Hz}$ at $121.5 \mathrm{MHz}$, giving $0.070 \mathrm{ppm}$ for $\delta \delta$. The larger pair of diastereomeric shifts $\delta \delta\left(\mathrm{P}_{\mathrm{B}}\right)$, between the doublets of quartets, was measurable directly as 0.941 and $0.940 \mathrm{ppm}$. The observation of quartets was similar to the $\mathrm{P}_{\mathrm{B}}$ region of $\alpha-\mathrm{P}_{4} \mathrm{~S}_{3}(\mathrm{~S})\left(\mathrm{SCHMeCH}_{2} \mathrm{I}\right) \mathrm{I}$, above. The two compounds have similar values of ${ }^{3} J\left(\mathrm{P}_{\mathrm{B}} \mathrm{P}_{\mathrm{D}}\right)$. This shows that the coupling is positive in the sulfurised dithiolate, as it is in $\alpha-\mathrm{P}_{4} \mathrm{~S}_{3} \mathrm{I}_{2}$ $(+9.3 \mathrm{~Hz})$, so that the average value which might be predicted by our balancing rules [2] for the sulfurised thiolate iodide would approximate to the observed values (Table 1). In contrast, the coupling ${ }^{3} J\left(\mathrm{P}_{\mathrm{B}} \mathrm{P}_{\mathrm{D}}\right)$ in unsulfurised $\alpha-\mathrm{P}_{4} \mathrm{~S}_{3}\left(\mathrm{SCHMeCH}_{2} \mathrm{I}\right) \mathrm{I}$ was almost zero, corresponding to the prediction that is should be the average of a negative coupling in $\alpha-\mathrm{P}_{4} \mathrm{~S}_{3}\left(\mathrm{SCHMeCH}_{2} \mathrm{I}\right)_{2}$ and the similar but positive coupling in the diiodide. Coupling ${ }^{3} J\left(\mathrm{P}_{\mathrm{B}} \mathrm{P}_{\mathrm{D}}\right)$ in $\alpha-\mathrm{P}_{4} \mathrm{~S}_{3}(\mathrm{~S})\left(\mathrm{NPr}_{2}^{\mathrm{i}}\right)_{2}$ is also positive [3], in contrast to the unsulfurised diamide.

The $\mathrm{P}_{\mathrm{C}}$ region was complicated similarly by accidental equalities, and appeared at $121.5 \mathrm{MHz}$ as a doublet $\left({ }^{1} J\left(\mathrm{P}_{\mathrm{C}} \mathrm{P}_{\mathrm{D}}\right)\right)$ of triplets $\left({ }^{2} J\left(\mathrm{P}_{\mathrm{A}} \mathrm{P}_{\mathrm{C}}\right)\right.$, larger $\left.\delta \delta\left(\mathrm{P}_{\mathrm{C}}\right)\right)$ of triplets $\left({ }^{2} J\left(\mathrm{P}_{\mathrm{B}} \mathrm{P}_{\mathrm{C}}\right)\right.$, smaller $\left.\delta \delta\left(\mathrm{P}_{\mathrm{C}}\right)\right)$. The first triplet splitting could be resolved into a doublet $\left(\delta \delta\left(\mathrm{P}_{\mathrm{C}}\right)\right)$ of doublets $\left({ }^{2} J\left(\mathrm{P}_{\mathrm{A}} \mathrm{P}_{\mathrm{C}}\right)\right)$ by remeasurement at $202.5 \mathrm{MHz}$, confirming the common coupling with the $\mathrm{P}_{\mathrm{A}}$ multiplets. The larger pair of shifts $\delta \delta\left(\mathrm{P}_{\mathrm{C}}\right)$ was 0.483 and $0.485 \mathrm{ppm}$. The second triplet splitting (average value $0.055 \mathrm{ppm}$ ) was not resolved at the higher frequency.

The resulting best estimates for chemical shifts of the diastereomers (in order of frequency in each region) and average couplings (over all diastereomers) were as follows. Chemical shifts: $\mathrm{P}_{\mathrm{A}} 56.91,56.70,55.04,54.84 ; \mathrm{P}_{\mathrm{B}}$ 161.77, $161.70,160.83,160.76 ; \quad \mathrm{P}_{\mathrm{C}} 140.63,140.57,140.14$, 140.08 ppm. Couplings: ${ }^{2} J\left(\mathrm{P}_{\mathrm{A}} \mathrm{P}_{\mathrm{C}}\right)$ 59.9; ${ }^{1} J\left(\mathrm{P}_{\mathrm{A}} \mathrm{P}_{\mathrm{B}}\right)$-381.6; ${ }^{1} J\left(\mathrm{P}_{\mathrm{C}} \mathrm{P}_{\mathrm{D}}\right)-285.1 ;{ }^{2} J\left(\mathrm{P}_{\mathrm{A}} \mathrm{P}_{\mathrm{D}}\right) 42.9 ;{ }^{2} J\left(\mathrm{P}_{\mathrm{B}} \mathrm{P}_{\mathrm{C}}\right)$ ca. $9 ;{ }^{3} J\left(\mathrm{P}_{\mathrm{B}} \mathrm{P}_{\mathrm{D}}\right)$ ca. $9 \mathrm{~Hz}$.

As might be expected, ${ }^{1} J\left(\mathrm{P}_{\mathrm{A}} \mathrm{P}_{\mathrm{B}}\right),{ }^{2} J\left(\mathrm{P}_{\mathrm{B}} \mathrm{P}_{\mathrm{C}}\right)$ and $\delta\left(\mathrm{P}_{\mathrm{B}}\right)$ had similar values to those in $\alpha-\mathrm{P}_{4} \mathrm{~S}_{3}(\mathrm{~S})\left(\mathrm{SCHMeCH}_{2} \mathrm{I}\right) \mathrm{I}$, and $\delta\left(\mathrm{P}_{\mathrm{A}}\right)$, though lower by $12.92 \mathrm{ppm}$, was in the same region of the spectrum. Just as $\delta\left(\mathrm{P}_{\mathrm{C}}\right)$ was much higher in the sulfurised thiolate iodide $(141.45 \mathrm{ppm})$ than in the unsulfurised compound (114.67), so here it was even higher (140.36) compared with the unsulfurised dithiolate (103.61). This may show the effect of a balancing of a higher $\delta\left(\mathrm{P}_{\mathrm{C}}\right)$ with the lower value of $\delta\left(\mathrm{P}_{\mathrm{A}}\right)$, as seen for previous, unsulfurised compounds [9]. The coupling ${ }^{1} J\left(\mathrm{P}_{\mathrm{C}} \mathrm{P}_{\mathrm{D}}\right)$, to the unsulfurised $\mathrm{P}_{\mathrm{D}}$ carrying the thiolate substituent, had a similar value to that in the unsulfurised dithiolate.

\section{Conclusions}

Methylthiirane 3 does not sulfurise $\alpha-\mathrm{P}_{4} \mathrm{~S}_{3} \mathrm{I}_{2}(\mathbf{1}, \mathrm{X}=\mathrm{Y}=\mathrm{I})$ at $60{ }^{\circ} \mathrm{C}$, nor at $21^{\circ} \mathrm{C}$ in the presence of $\operatorname{Re}(\mathrm{O}) \mathrm{Cl}_{3}\left(\mathrm{PPh}_{3}\right)_{2}$, but under either conditions it will sulfurise the resulting insertion product exo,exo- $\alpha-\mathrm{P}_{4} \mathrm{~S}_{3}\left(\mathrm{SCHMeCH}_{2} \mathrm{I}\right) \mathrm{I} \quad(\mathbf{1}, \mathrm{X}=$ $\left.\mathrm{SCHMeCH}_{2} \mathrm{I}, \mathrm{Y}=\mathrm{I}\right)$, to give $\alpha-\mathrm{P}_{4} \mathrm{~S}_{3}(\mathrm{~S})\left(\mathrm{SCHMeCH}_{2} \mathrm{I}\right) \mathrm{I} 2$, in which the added, 1-coordinate, sulfur atom is attached to the same phosphorus atom as the thiolate group $\mathrm{SCHMeCH}_{2} \mathrm{I}$. Under the thermal conditions, one sulfur atom was added similarly to the diinsertion product exo,exo$\alpha-\mathrm{P}_{4} \mathrm{~S}_{3}\left(\mathrm{SCHMeCH}_{2} \mathrm{I}\right)_{2}$. Jason concluded that rates of addition of sulfur from $\mathrm{Ph}_{3} \mathrm{AsS}$, to binary phosphorus sulfides, increased with the number of bridging sulfur atoms already attached to the phosphorus to be sulfurised [15]. He expressed this in terms of the local oxidation state of this phosphorus (i.e. number of 2-coordinate sulfur ligands rather than 3-coordinate phosphorus ligands), but in the present work we show that replacing an iodide substituent by thiolate, with no change in oxidation state, also promotes sulfurisation. Two bridging sulfur atoms, $S_{a}$ and $S_{d}$ (Scheme 1) were insufficient to allow sulfurisation of the $\alpha-P_{4} S_{3}$ cage 1 at $\mathrm{P}_{\mathrm{A}}$, but $\mathrm{S}_{\mathrm{b}}$ and the sulfur of the thiolate group were sufficient for sulfurisation at $P_{B}$. Thiolate sulfur is likely to be a better $\pi$-donor to phosphorus than bridging, cage sulfur (and certainly than iodide), and it is probably the extent of $\Pi$-donation which controls susceptibility to sulfurisation.

\section{Experimental Section}

All operations were carried out under nitrogen by Schlenk methods. $\mathrm{CS}_{2}$ was dried by distillation from $\mathrm{P}_{4} \mathrm{O}_{10}$. $\alpha-\mathrm{P}_{4} \mathrm{~S}_{3} \mathrm{I}_{2}$ was prepared by reaction of $\mathrm{P}_{4}, \mathrm{~S}_{8}$, and $\mathrm{I}_{2}$ in $\mathrm{CS}_{2}$ [16]. Methylthiirane 3 and $\mathrm{Re}(\mathrm{O}) \mathrm{Cl}_{3}\left(\mathrm{PPh}_{3}\right)_{2}$ (Aldrich) were used as received. ${ }^{31} \mathrm{P} \mathrm{NMR}$ spectra were measured in $10 \mathrm{~mm}$ diameter tubes at $294 \mathrm{~K}$ using a Bruker WM300WB spectrometer operating at $121.5 \mathrm{MHz}$, or using a Jeol Lambda 500 spectrometer at $202.5 \mathrm{MHz}$. Inverse-gated ${ }^{1} \mathrm{H}$ decoupling was used to suppress proton coupling while avoiding the Nuclear Overhauser Effect. Precision capillaries containing $\left(\mathrm{CD}_{3}\right)_{2} \mathrm{CO}$ were used for locking. Chemical shifts are reported relative to $\mathrm{H}_{3} \mathrm{PO}_{4}$-water. ${ }^{13} \mathrm{C}$ NMR spectra and DEPT measurements were obtained using the Jeol spectrometer. $\mathrm{Ab}$ initio calculations were carried out using Gaussian 98 [17].

Typical experiment: reaction of $\alpha-P_{4} S_{3} I_{2}$ with methylthiirane in the ratio $1: 2$.

$\alpha-\mathrm{P}_{4} \mathrm{~S}_{3} \mathrm{I}_{2}(0.5 \mathrm{~g}, 1.055 \mathrm{mmol})$ was dissolved in $\mathrm{CS}_{2}\left(20 \mathrm{~cm}^{3}\right)$, and rac-methylthiirane $\left(0.165 \mathrm{~cm}^{3}, 2.11 \mathrm{mmol}\right)$ was added. The solution was stirred at $21{ }^{\circ} \mathrm{C}$ in the dark for 22 hours. A part (a) $\left(10 \mathrm{~cm}^{3}\right)$ of the clear yellow solution was treated with $\mathrm{Re}(\mathrm{O}) \mathrm{Cl}_{3}\left(\mathrm{PPh}_{3}\right)_{2}$ (40 mg, $0.048 \mathrm{mmol}$ ), to give a dark brown solution after a few minutes, which was stirred for a further 5 hours at $21{ }^{\circ} \mathrm{C}$. The remainder (b) of the original solution was heated to reflux (bath temperature $60^{\circ} \mathrm{C}$ ) for 5 hours, with no change in appearance. Samples of all three solutions were analysed by NMR, as described above.

Supporting Information (see footnote on the first page of this article): rotatable ab initio molecular models as Chime/Rasmol spt files or .xyz coordinate files; corresponding energies.

\section{Acknowledgments}

We thank Dr. M.N.S. Hill and Prof. W. McFarlane for help in obtaining NMR spectra.

[1] B. W. Tattershall, R. W. Houghton, D. J. Martin, Z. Anorg. Allg. Chem. 2004, 630, 1991. 
[2] B. W. Tattershall, J. G. Knight, M. J. Andrews, C. L. Booth, Z. Anorg. Allg. Chem. 2006, 632, 425.

[3] B. W. Tattershall, E. L. Sandham, Z. Anorg. Allg. Chem., 1996, 622, 1635.

[4] J. B. Arterburn, M. C. Perry, Tetrahedron Lett. 1997, 38, 7701.

[5] B. W. Tattershall, C. Boylan, S. L. Gummerson, J. A. Mowatt, unpublished work.

[6] S. Z. Ivin, I. D. Shelakova, Russ. J. Gen. Chem., 1965, 35, 1224.

[7] B. W. Tattershall, J. Chem. Soc., Dalton Trans., 1985, 1707.

[8] B. W. Tattershall, N. L. Kendall, Polyhedron, 1994, 13, 1507.

[9] B. W. Tattershall, J. Chem. Soc., Dalton Trans., 1991, 483.

[10] H. P. Baldus, R. Blachnik, P. Lönnecke, B. W. Tattershall, J. Chem. Soc., Dalton Trans., 1991, 2643.

[11] B. W. Tattershall, K. E. Holmes, C. Tweedy, G. C. Valks, Z. Anorg. Allg. Chem. 2008, 634, 1703.

[12] C. J. Pouchert, The Aldrich Library of ${ }^{13} \mathrm{C}$ and ${ }^{1} H \mathrm{NMR}$ Spectra, Aldrich Chemical Co., Milwaukee, 1993.

[13] A. R. Quirt, J. S. Martin, K. M. Worvill, NUMARIT, Version 771, SERC NMR Program Library, Daresbury, 1977; http://www.staff.ncl.ac.uk/bruce.tattershall/software

[14] B. W. Tattershall, J. G. Knight, M. J. Andrews, Z. Anorg. Allg. Chem. 2007, 633, 1442.

[15] M. E. Jason, Inorg. Chem. 1997, 36, 2641.
[16] B. W. Tattershall, N. L. Kendall, A. McCamley, W. Clegg, Acta Crystallogr., Sect. C, 1993, 49, 571.

[17] M. J. Frisch, G. W. Trucks, H. B. Schlegel, G. E. Scuseria, M. A. Robb, J. R. Cheeseman, V. G. Zakrzewski, J. A. Montgomery, Jr., R. E. Stratmann, J. C. Burant, S. Dapprich, J. M. Millam, A. D. Daniels, K. N. Kudin, M. C. Strain, O. Farkas, J. Tomasi, V. Barone, M. Cossi, R. Cammi, B. Mennucci, C. Pomelli, C. Adamo, S. Clifford, J. Ochterski, G. A. Petersson, P. Y. Ayala, Q. Cui, K. Morokuma, D. K. Malick, A. D. Rabuck, K. Raghavachari, J. B. Foresman, J. Cioslowski, J. V. Ortiz, A. G. Baboul, B. B. Stefanov, G. Liu, A. Liashenko, P. Piskorz, I. Komaromi, R. Gomperts, R. L. Martin, D. J. Fox, T. Keith, M. A. Al-Laham, C. Y. Peng, A. Nanayakkara, C. Gonzalez, M. Challacombe, P. M. W. Gill, B. Johnson, W. Chen, M. W. Wong, J. L. Andres, C. Gonzalez, M. Head-Gordon, E. S. Replogle, J. A. Pople, Gaussian 98, Revision A.7, Gaussian Inc., Pittsburgh, PA, 1998.

Scheme 1. Atom labelling and enantiomer definition for $\alpha-\mathrm{P}_{4} \mathrm{~S}_{3}$ skeletons 1 and $\alpha-P_{4} S_{3}(S)$ skeletons 2 . Methylthiirane 3.

Scheme 2. Proposed mechanism for insertion of methylthiirane into the $\mathrm{P}_{\mathrm{B}}$-I bond of $\alpha-\mathrm{P}_{4} \mathrm{~S}_{3} \mathrm{I}_{2}$ (1a).

Received: ((will be filled in by the editorial staff)) Published online: ((will be filled in by the editorial staff)) 